\section{Наталія Кондель-Пермінова Nataliya Kondel-Perminova \\ кандиАат архітектури, завідувач відАіку дизайну Candidate in Architecture, Head of the Department й архітектури IПСМ НАМ України of Design and Architecture of the Modern Art Research Institute of the National Academy of Arts of Ukraine}

\author{
Олександра Хамепа Oleksandra Khalepa \\ молоАший науковий співробітник віААіку Аизайну \\ і архітектури, ІПСМ НАМ України \\ junior researcher, Department of Design and Archi- \\ tecture of the Modern Art Research Institute of the \\ National Academy of Arts of Ukraine \\ e-mail: khalepa@mari.kiev.ua | orcid.org/0000-0002-6104-0132
}

\title{
The Role of Art Developer in the Formation of Contemporary Art Practices
}

\begin{abstract}
Анотація. Наповнення просторів занедбаних промислових територій новим змістом $є$ актуальною проблемою сьогодення. Успішний редевелопмент постіндустріальних мокацій, приАатних Аля розгортання новітніх мистецьких практик, можливий за мультивекторної практики діяча нового типу — арт-девелопера, поняття якого вводиться до наукового обігу. Аіяльність арт-девелопера розглядається як особливе мистецтво мікшування і виконання низки функцій, притаманних, зокрема, куратору, арт менеджеру й девелоперу. На прикладі авторського експериментального проєкту арт-резиденції «Карбон» (Київ) проаналізовано основний зміст роботи арт-девелопера, яка розгортається у проєктному піАході і склаАається з трьох основних стадій: концепція — проєкт — реалізація. Викладено мистецькі напрацювання у різних творчих форматах, апробованих в артрезиденції «Карбон».
\end{abstract}

Ключові слова: куратор, арт-девелопер, арт резиденція «Карбон», експеримент, проєкт, мистецтво нових меАіа.

Постановка проблеми. На межі XX-XXI століть постраАянські міста України зазнають істотних змін, зумовмених нівелюванням ролі промисловості як провіАного чинника урбаністичного розвитку. Посилюється суспільна увага Ао занеАбаних промислових територій, Ао чисменних спустошених буАівель заводів, фабрик, складів, суднобудівельних Аоків. Все більше унаочнюється пробцема введення їх у контекст сучасного міського життя. Переважна більшість фахових пропозицій стосовно поАальшого використання постіндустріальних об'єктів стосується мише робіт з їхньою матеріальною «оболонкою». Тоді як наповнення просторів промислового спадку новим змістом, інтегрування культурно-мистецьких практик у середовище індустріальних споруА виходить за межі фахових розгляАів.

Світовий АосвіА містить чимало доказів альтернативного застосування «старого прому» як сучасних публічних просторів та осередків креативних індустрій. Є. ВАасенко наводить низку чинників привабливості постіндустріальних просторів, а саме «гнучкість і віАсутність необхіАності у великих капіталовкиаденнях, що розширює можливості використання простору та позначається на Аоступності послуг, надаваних у ньому, Аля широкого загалу. Окремий чинник - наявність певної ініціативної групи (організації, територіальної спільноти або субкультури), що виступає ідеологом і Авигуном простору, навколо якого формується аудиторія користувачів простору. Саме таких “стрижневих” спільнот часто позбавлено проєкти нових просторів, що плануються у традиційний спосіб, через бізнесові та Аержавні структури» [1, с. 259].

Розгортання масштабних трансформаційних процесів на колишніх промислових мокаціях можливе за умов консоліАації зусиль різних Аієвців - митців, 
кураторів, менеАжерів, Аевелоперів, критиків, преАставників влади, бізнесу, громаА тощо. У зв'язку з цим активізується потреба у «синергетичному» Аіячі, мультивекторна Аіяльність якого є специфічним мистецтвом мікшування та виконання низки функцій, притаманних різним фахівцям.

Аналіз останніх досліджень і публікацій. Останні АосліАження проблем освоєння колишніх промислових просторів в Україні можна розгляАати у Авох піАхоАах. Перший охоплює пошуки їхнього нового значення та функцій. ІАеться про розробки концепцій регенерації індустріальних територій, що мають різні передумови, різні ступені занедбаності. У цьому контексті посимюється увага Ао створення культурно-мистецьких кластерів як міських просторів із різноманітними функціями, які активовані цілорічно й цілодобово і де Аюдина може бути як гмяАачем, так і активним учасником мистецьких подій. Концептуальні напрацювання видозмін промисмових об’єктів на нові публічні простори, культурні зони та кластери найбільш результативно зАійснюються у форматах воркшопів, Ао роботи в яких залучено значну кількість учасників. СереА приклаАів - Міжнародний урбаністичний воркшоп «Фрунзе, 35 - переосмислюємо промзону» $[2 ; 3]$.

У Аругому підході подається досвіА освоєння новітніми мистецькими практиками колишніх індустріацьних мокацій, аАже кожна з них потребує індивіАуального розгляАу, віАповіАної аналітики, розробки концепції та проєктів видозмін. На культурній мапі Києва й України визнаною фмагманською структурою $є \ll$ Мистецький Арсенам», освоєння занедбаного простору якого як всеукраїнського центру культурних ініціатив розпочалося у 2007 році з першого фестивалю ГОГО $\Lambda$ bFEST. Фестивальний формат виявився найбільш дієвим і сприятАивим Аля розгортання трансформаційних процесів. Так, ГОГОАЬFЕSТ став поштовхом Ао поАацьших Аій стосовно наповнення альтернативними мистецькими акціями інших постіндустріальних зон Києва (ВАНХ, Теличка, Аовженко-Центр, кіностудія ім. О. Аовженка, арт-завоА «Пиатформа») $[4 ; 5]$.

Залученню до життя міст «старого прому», потенційно вельми приАатного Аля розгортання гри мистецтв із суспільними реаліями, суттєво сприяють експериментальні креативні практики [6]. УнасліАок взаємодї значної кількості мюАей (митців, кураторів, арт менеАжерів тощо), перетину архітектурного і кумьтурно-мистецьких просторів окреслюються нові вектори урбаністичного розвитку міст. Результати АосліАжень цих процесів висвітмено у працях М. Квона, Б. Тейлова, Е. Гарні, М. Аінгера, А. Харлінга, Н. Гончаренко, Н. Мусієнко, О. Чепелик, П. Шугурова, Г. Фірсова, Н. Барсукової, П. Войницького, А. Контиоманова, А. Зайця та інших.

Мета статті: аналіз принципових засаА мультивекторної практики Аіяча нового типу, спрямованої на реАевемопмент постіндустріальних мокацій, придатних Аля розгортання новітніх мистецьких практик, і введення до наукового обігу поняття «арт-девелопер».
ВиклаА основного матеріалу. Перетворення постінАустріальних мокацій на культурно-мистецькі кластери $\epsilon$ важливим і перспективним напрямом їхнього реАевелопменту. Колишні індустріальні об’єкти мають чималі площі, значну висоту приміщень із великопрогоновим перекриттям, тому Аосить сприятливі Аля формування різних виАів і форматів арт-практик, реалізації інтерактивних проєктів і численних експериментів. Приміром, відеомеппінг можна Аемонструвати на великих стінах із максимальним розкриттям візуального задуму, те ж стосується й розробки та експонування інтерактивних скульптур. ВіААаленість промзон віА житла Аає змогу розгортати тут саунА-артпроєкти 3 максимальним розкриттям звучання звукових об'єктів. Крім того, постіндустріальні території досить значні і це $є$ важливою умовою Аля реалізації численних проєктів і експериментів, поєАнання різних меАіаартпрактик і наповнення векиких просторів грою світла, тіні, звуку, форми, візуального ряду.

Аослідження іноземного та вітчизняного АосвіАу трансформацій колишніх індустріальних споруА й авторська рефлексія власних експериментальних робіт на постіндустріальних мокаціях зумовили необхіАність студіювання різнобічної практики Аіяча нового типу арт-девелопера, і цю позицію пропонуємо ввести до наукового обігу. Аіяльність арт-девелопера розглядається як особливе мистецтво мікшування і виконання низки функцій, притаманних, зокрема, куратору, арт-менеАжеру й Аевелоперу.

Як і куратор, арт-Аевелопер перебуває в епіцентрі художнього процесу, сприяє розвитку мистецького середовища шляхом участі у розробці концепції проєкту, комунікації з авторами тощо. Кураторська іпостась артАевелопера $є$ провідною, тому він повинен добре знатися на специфіці кураторства, його Аинамічній класифікації (за Є. Герман): музейний куратор, незалежний куратор, куратор бієнале, перформативний куратор, новітні типи кураторства (постпрезентаційне, паракураторство). I, віАповіАно Ао кураторського фаху, постійно піАживлюватися новітніми авторськими методами поза сталими класифікаціями [6].

Управлінська діяльність арт-девелопера є поАібною Ао роботи арт менеАжера, яка охопиює процес створення й просування арт-продукту. СереА функцій артменеАжера - концептуальна розробка мистецької проАукції, організаційно-управлінські Аії, маркетинг, зв'язки з громадськістю та реклама, комерційна, фінансово-економічна й юридично-правова складові. Арт-менеджер зАійснює значний вплив на формування громаАської Аумки, суАжень і смаків публіки. Його поле Аіяльності Аосить широке й різноманітне, як і виАи креативного продукту. Артменеджер формує процес створення мистецького проєкту, віАповіАно набирає виконавців, налагоджує роботу в команді, організовує могістику творів, візуальне оформмення проєкту. Зазвичай кураторські й арт-менеАжерські функції є взаємообумовленими.

Постіндустріальні мокації є майданчиками з нерухомим майном, тому у цей науковий Аискурс ввоАиться 


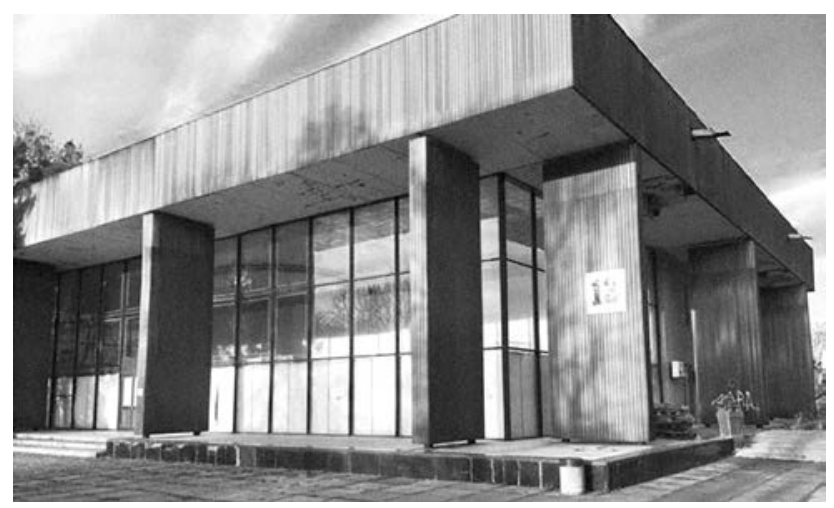

Загамьний вигляА 13-го павільйону ВАНГ

позиція девелопера. Як відомо, девелопмент - розвиток територій, зАійснення низки Аій (проєктних, буАівельних тощо) з метою Аосягнення якісних змін земельних Аілянок шияхом створення об'єктів нерухомості. На збільшення їхньої вартості і спрямована піАприємницька Аіяльність девелопера. Тому позиція девелопера охоплює авторство іАеї (концепції) проєкту, функції набувача земельної Аілянки піА забудову, інвестора, організатора процесів проєктування, буАівництво об’єкта, керуючого нерухомістю тощо.

Оскільки йдеться про постіндустріальні споруАИ, тобто існуючі об'єкти нерухомості, провіАним є реАевелопмент - процес їхнього перепрофілювання піА інше призначення. Редевелопмент колишніх індустріальних об'єктів значно склаАніший, ніж Аевелопмент неосвоєних земельних Аілянок. У таких ситуаціях девелопер має знайти віАповіАь на низку ключових питань, сереА яких визначення ефективного напряму подацьшого використання нерухомості (знесення або реконструкція), розробка концепції (визначення нової якості об'єкта нерухомості й кола його майбутніх користувачів). Аалі, за наявності концепції, схема редевелопменту переАбачає проведення переговорів з потенційними орендарями з метою визначення їхніх інтересів. За потребою проводиться коригування концепції і далі відбувається розробка проєктної документації, зАійснюються будівельні роботи і оновлений об'єкт нерухомості вводять до експиуатації.

У цьому контексті основним змістом Аіяльності артАевелопера (яка розгортається у проєктному піАході і складається з трьох основних стадій: концепція - проєкт - реалізація) є креативний редевелопмент постіндустріальних об'єктів із потужним застосуванням мистецьких практик.

На першій, концептуальній стаАії визначають нову якість об'єкта нерухомості і коло майбутніх користувачів. Ао цих робіт арт-девелопер закучає спільноти ${ }^{1}$, організовує групову роботу та публічну комунікацію. На цій стадії

1 Спімьноти - це групи мюАей, Аіяльнісно об'єАнані навколо спільних іАей, цінностей. Існує кілька типів спільнот: Аокальна (що гуртується навколо певної мокації або місця проживання), тематична (навколо певної теми або проєкту), тимчасова (залежить віА часу спільного перебування), по інтересам (різноманітні гуртки, клуби тощо). він переважно виконує функції фасилітатора й, віАповіАно Ао особливостей ситуації, застосовує той чи інший формат комунікації. Після провеАених АосліАжень на різних мокаціях України експериментально визначено кілька ефективних форматів взаємодії спільнот, сереА яких провідним є фестиваль, що охоплює низку інших видів взаємодії: майстер-клас, тренінг, публічна мекція, вебінар, форум, конференція, воркшоп. Ці формати дозволяють оперативно розгортати експериментальні майданчики й за короткий термін розкривати креативний потенціал спільнот.

На Аругому етапі опрацьовують арт-девелоперський проєкт із чітким визначенням напрямів, форматів Аіяльності та необхідних ресурсів. Зміст третього етапу реалізація наявного й узгоАженого проєкту. У піАсумку колишні промислові мокації перетворюються на «треті місця ² Аля арт-спільнот і віАвіАувачів. Поняття «третє місце» розгляАається у контексті креативних індустрій, нових форм діяльності з притаманним їм застосуванням й органічним поєАнанням знань, інформації і творчості. Креативні індустрії, Аля яких головною цінністю $є$ іАеї (концепти), нівелюють межі між країнами, наукою та мистецтвом і найбільш виразно проявляються у міському середовищі. Їм притаманні культурна й етнічна різноманітність, акцентування на унікальності кожної цокації, орієнтація на мамий бізнес.

\section{Особцивості арт-Аевемоперського проєктування}

Виокремлені особливості діяльності арт-девелопера $\epsilon$ результатом аналізу виконаних О. Хамепою впродовж 2014-2020 років низки експериментацьних робіт на різних постіндустріальних мокаціях України. Найбільш показовим у цьому сенсі $\epsilon$ авторський арт-девелоперський проєкт «Карбон». Концепція пристосування 13-го павільйону ВАНГ (Національний комплекс «Експоцентр України») піА арт-резиденцію (автор О. Халепа) була опрацьована на конкурсних засадах після завершення десятого фестивалю ГОГОАЬFЕST-2017. Пропозиція була визнана найкращою й рекомендована до реалізації.

Павільйон № 13 (Аамі мокація П13), початкова назва якого - «Вугільна промисловість», є спорудою 3 Авома поєАнаними частинами: надземною та піАземною. Підземна частина вирішена у вигляді макета шахти з Авома паралельними галереями завдовжки 55 м і заввишки 2,5 м, Авома поперечними 20-метровими штреками та місцями, Ае встановлено обладнання Аля добутку вугіляя. Наземна частина — павільйон загальною площею 1800 кваАратних метрів із великим заскиеним фасадом.

ЗгіАно з авторською концепцією ця мокація мала перетворитися на пиатформу взаємоАї Аіячів театру, синтезу сучасного мистецтва, медіа, музики, танцю, кіно тощо,

\footnotetext{
2 Третє місце» (ангм. the third place) - частина міського простору, яка не пов'язана з домом («перше місце») або роботою («Аруге місце»). СереА приклаАів «третього місця» - кафе, клуб, бібміотека тощо.
} 
тобто на арт-резиденцію - мумьтифункціональний простір, Ае АюАи, об'єАнуючись у групи, обмінюються іАеями, Аумками, знаходять партнерів Аля імплементації інноваційних проєктів.

Концепція опрацьована на чотирьох рівнях. На першому (Аокальному), арт-резиденція преАставлена як хуАожня модель ВАНГ - простір Аля розвитку особистості, культурного Аозвіляя, як сереАовище Аля формування іАей і розвитку талантів. Це територія, Ае створюються нові цінності, каталізатор примноження культурного капіталу країни - інвестиція у процвітання й добробут майбутніх поколінь. Також передбачалася взаємодія арт-резиденції з усіма кластерами мокації із залученням до спільних проєктів ВАНГ.

На Аругому, загальноміському, рівні (м. Київ), артрезиденція замислювалася як потужний об'єкт міського кумьтурно-мистецького помя. Шияхом об'єАнання з іншими Аружніми проєктами і мистецькими мокаціями переАбачалося створення системи зв'язків й обміну АосвіАом, інформацією та ресурсами. На міжрегіонацьному рівні (Україна) арт-резиденція маха виконувати роль Арайвера інновацій та культурних індустрій; місця, що об'єАнує різні регіональні культурно-мистецькі ініціативи, а також своєріАних «воріт» у країну Аля іноземних митців.

Аця формування потужної арт-резиденції світового значення, налагодження взаємодії між українськими й іноземними митцями, створення сприятливого сереАовища Аля вироблення спільного мистецького продукту концепцією охоплено й міжнародний рівень. СереА провіАних завдань арт-резиденції - популяризація спадщини і сучасної культури України, актуалізація українського мистецтва, співпраця з іншими вітчизняними й іноземними культурно-мистецькими інституціями, участь у міжнародних проєктах, виставкова, наукова і просвітницька Аіяльність.

Освоєння простору колишнього павільйону вугільної промисловості (П13), згіАно з наявною концепцією, розпочалося піА проводом арт-девелопера у мистопаАі 2017 року з формування спільноти, зацікавленої у розвитку мокації, шляхом проведення кількох тестових мистецьких заходів, прибирання приміщень, здійснення спільнокоштом ремонтних робіт, розробки власного бренду $\ll$ Карбон ».

В основі бренду «Карбон» - назва хімічного елементу з атомним номером 6 (вугмець або карбон), який існує у кількох модифікаціях: алмаз, графіт, вугіля, сажа. Творення аммазів піА Аією високих тиску та температур метафорично втілено у найменуванні мокації П13 як артрезиденції «Карбон», де процес творення нових мистецьких поАій та кумьтурних продуктів віАбувається на межі протилежностей: між темним і світлим, між вугілмям і алмазом, між поверхнею та піАземемлям, між мейнстримом і андеграундом. Цей процес «матеріалізується» у Авох головних приміщеннях: «вугільній» шахті й «алмазній» галереї, між якими існує постійна комунікація і простір яких наповнюється мистецькими подіями.
Аоготип «Карбон»

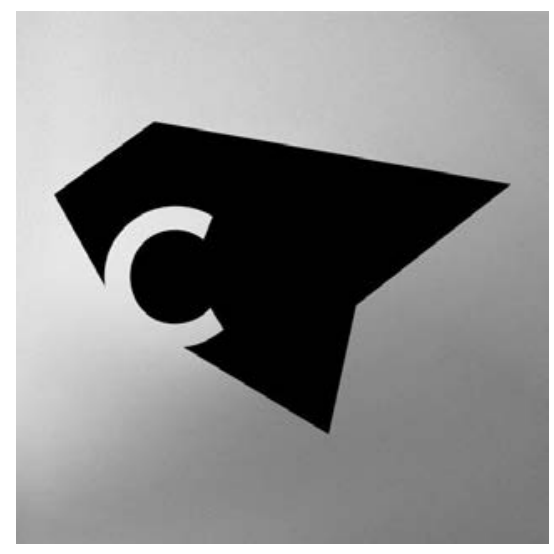

Перший етап Аій на Аокації П13 (Аистопад 2017 — мистопаА 2018) - час формування сприятливого сереАовища Аля прояву різних мистецьких практик, провеАення низки експериментальних заходів з метою визначення головного напрямку Аіяльності арт-резиденції. Цей етап (за умов обмежених фінансових, часових та мюАських ресурсів) потребував віА арт-девелопера особливих організаційних та управлінських зусиль і спонукав до потужної концентрації зусиль і прояву високого рівня креативності. Кожна поАія віАбувалася у форматі мокального проєкту. Початкова ідея проведення заходу оформикася у концепцію піА конкретних митців і преАставників спільноти мокації. Проєкт кожного заходу (фестиваль, виставка, концерт, мекція, форум тощо) розробмяли спікьними зусимяями артАевелопера і кураторів з урахуванням наявних ресурсів.

Унаслідок першого етапу провіАним напрямом мистецької резиденції визнано меАіамистецтво як таке, що Аоповнює поАії, піАсилює інші мистецтва, віАповіАає сучасним творчим тенденціям і піАкреслює образність та унікальність мокаціі. Простір резиденції виявився потенційно придатним Аля формування мистецьких спільнот шляхом освіти (Аабораторії) та просвіти віАвідувачів мистецьких захоАів П13, знайомства з творчими Аоробками митців. Низова мистецька ініціатива в особі артАевелопера і сформованої навколо нього спільноти артрезиленції «Карбон» набула певного Аосвіду, отримала перші мистецькі продукти, Аовела свою спроможність наповнювати змістом і видозмінювати постіндустріальний простір. На локації П13 проведено десять міжнародних подій, АваАцять — колаборційних між Аіячами театру, сучасного, мистецтва, медіа, музики, танцю та кіно, з яких переважна більшість - Аля широкого загалу публіки. Кількість віАвідувачів склала понаА 10 тисяч осіб.

Річний експеримент на мокації П13 павільйону ВАНГ засвідчив актуальність і перспективність концептуальної іАеї експериментацьного простору Аля розвитку новітніх мистецьких практик і гуртування творчих мюдей. Чіткіше окреслилися суспільні потреби стосовно розвитку мистецького потенціалу громаАян, організації креативного Аозвіляя Аля різних вікових груп віАвіАувачів ВАНГ. ПіАтверАжено місію арт-резиденції «Карбон» щодо створення простору Аля появи інноваційних художніх практик, самореацізації арт-спільнот і мистецької просвіти віАвідувачів ВАНГ. 


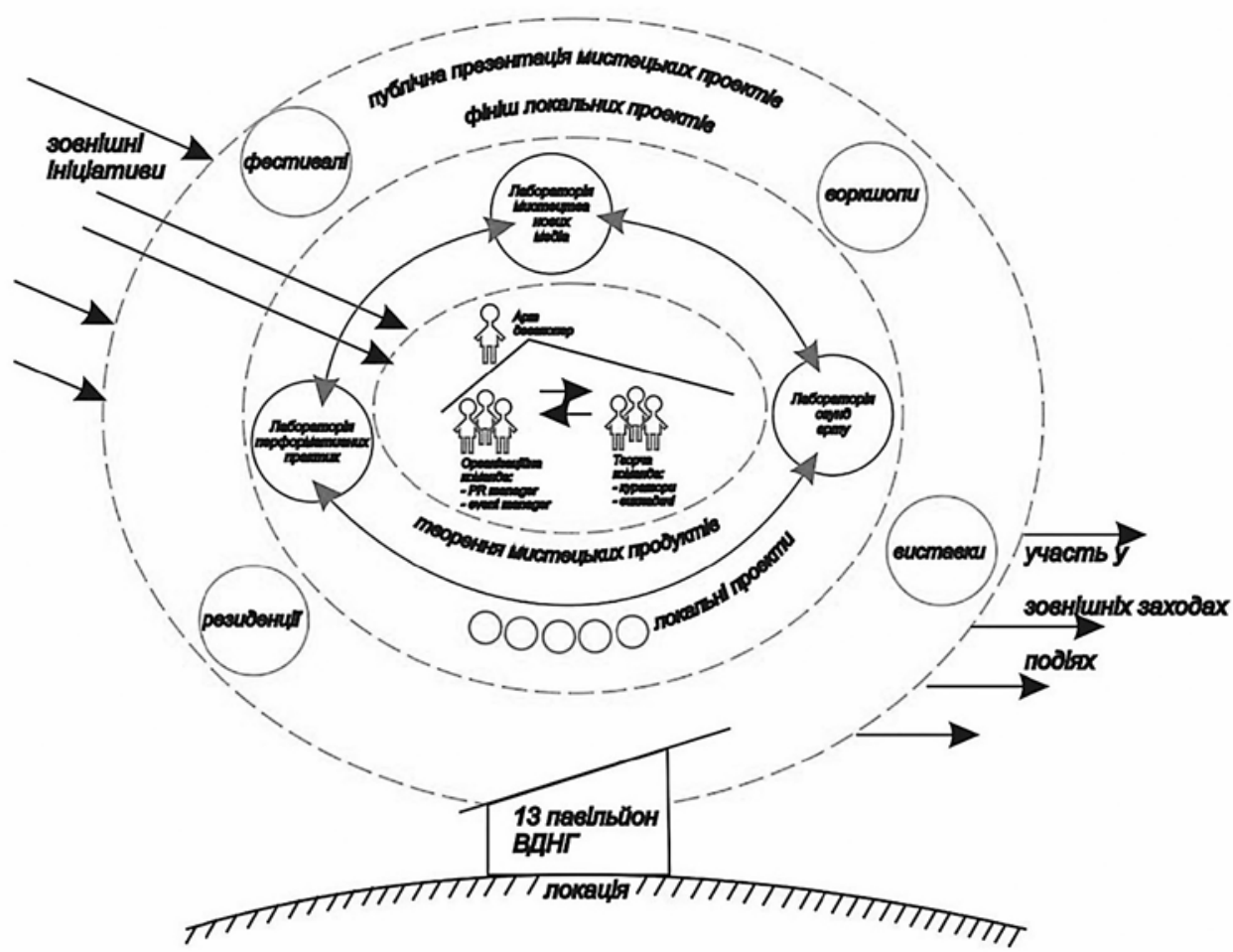

Зміст і структура арт-Аевемоперського проєкту «Карбон»
Базові уявлення про зміст і структуру Аіяльності арт-девелоперського проєкту «Карбон» преАставлено на схемі, в яАрі якої - взаємодія та співпраця Авох команА: організаційної й творчої. Організаційна команда (арт-девекопер, аАміністратор павільйону, Аизайн-менеАжер, технічний менеАжер, івент-менеАжер, файндрайзер, PR-менеАжер, контент-менеАжер, координатор вомонтерів, фотограф, відеограф) проєктує і просуває заходи, працює наА перетворенням мокації, супроводжує і забезпечує технічними ресурсами партнерів і резидентів, забезпечує порядок і безпеку. Творча команда (куратори мабораторій: медіаарту, саунА-арту, перформативних практик, куратори окремих проєктів, виклаАачі) працює наА створенням креативного продукту, який наповнює простір резиденції об'єктами різних виАів мистецтв. Координацію й взаємодію обох команА забезпечує арт-девелопер.

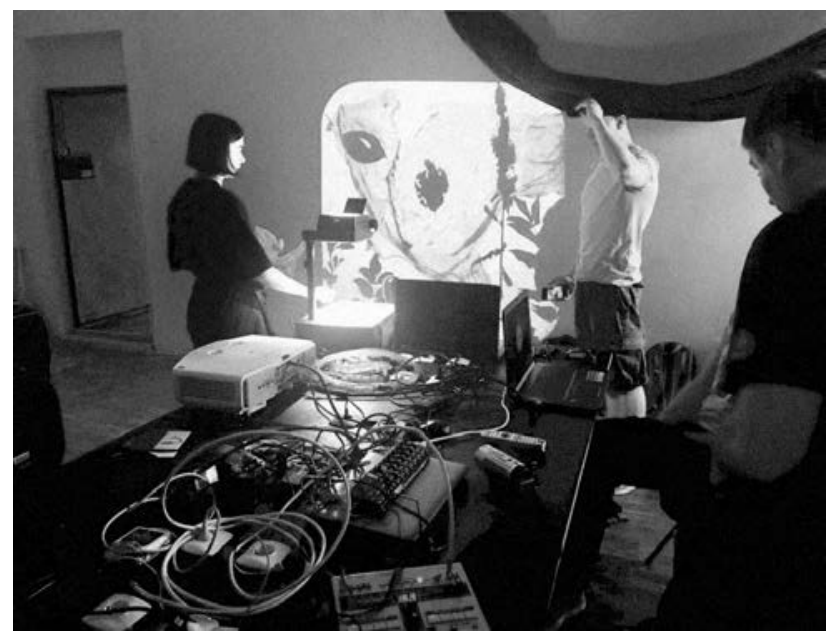

Медіа-експериментальна мабораторія «Технології та Творчість», 2018
Освітній напрям у Аіяльності арт-резиденції «Карбон», спрямований на самоорганізацію й розвиток творчих особистостей (на схемі - перше концентричне коло), преАставлений у форматі трьох арт-лабораторій: саунАарт, меАіаарт та перформативних практик. Кожна з них працює автономно і генерує навчальні події, проведення тематичних виставок і резиденцій Аля художників.

Інтегрування $\Lambda$ абораторій, їхнє взаємне підсилення активностями, мистецькими продуктами відбувається піА час фестивалів, воркшопів, всеукраїнських та іноземних резиденцій, інших заходів «Карбону» (Аруге концентричне коло на схемі). Це коло публічної презентації створених мистецьких продуктів і - фініш чисменних мокацьних проєктів, який є важливою складовою проєкту «Карбон», оскільки Аозволяє гуртувати митців різного фаху, організовувати креативне Аозвілмя віАвіАувачів.

Арт-резиденція «Карбон» є віАкритою структурою А^я новітніх ініціатив, Аля участі у різноманітних зовнішніх заходах (третє коло на схемі). Ініціативи, що прихоАять ззовні, адміністративна команда аналізує, апробовує в мабораторіях та, у разі відповіАності напрямам резиденції, інтегрує у загальну концепцію «Карбону».

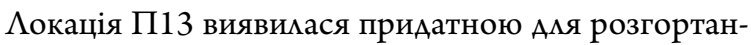
ня експериментальних пошуків як Аля мистецьких, так і Аля практик креативних індустрій, що й обумовило гомовний зміст арт-девелоперського проєкту «Карбон». 3Аійснені заходи продемонстрували можливості як окремої реалізації кожної з цих практик, так і їхнього симбіозу. Особливість арт-резиденції «Карбон» - освітнє піАГрунтя У вигляАі навчально-мистецьких мабораторій, Аіяльність яких піАтримується та супроводжується різними форматами публічних заходів. Створення мабораторій можливе за умови наявності кураторів. 
Аомінантний напрям Аругого етапу діяльності «Карбону» - меАіаарт - отримав розвиток у віАповіАній мабораторії, в якій розгорнулося вивчення можливостей застосування новітніх технологій у різних мистецьких практиках. Крім того, велися цікаві розробки з саунА-арту й перформансу. Креативні зАобутки (одинаАцять артоб’єктів) публічно представлено 1-17 мютого 2019 року на «Carbon Media Art Festival», а саме: інтерактивна світлова інсталяція «Інь і Янь» (авторка Оксана Бузяк); медіаарт-об’єкт «Нурnomat» піА авторством $\Lambda$ абораторії «Synestetica» платформи «Острів» (Київ); медіаартоб'єкт «Аескріптор» (автор Сергій Нежинський); казер «Звук» (автор Андрій Бут); «Нейронна мережа» - інстацяція віАомої мисткині медіаарту Оксани Чепелик; інтерактивна інсталяція «Touch the surface» (авторка Аарина Горбачова); інтерактивне зображення «Кіт» (автор Павло Гончаренко) та низка інших робіт.

СереА мистецьких напрацювань у рамках проєкту німецько-української резиденції «Re:main. Art residence», ініційованої арт-резиденцією «Карбон» і німецькою партнерською організацією «Trans-Media Akademie Hellerau» у просторі арт-резиденції «Карбон» (квітень 2019 року), презентовано саунА- та медіаарт-інстацяції, VR-інстацяції й аудіовізуальні виступи наживо. Робота «Humans» (авторка Аарина Фес) занурює глядача у віртуальну реальність, у кімнату з фігурами гуманоїдів, які реагують на присутність АюАини, шепочуть певні слова і тримаються на близькій віАстані оАин віА оАного. ГАяАач має пройти між ними, й у випаАку, коли мюАина торкається зображення, воно зникає. 3 кожним новим глядачем дія починається заново. ІАея проєкту полягає у тому, щоб зрозуміти наше сприйняття віртуацьних об’єктів і фізичного тіла; викликати відчуття близькості й тривожності.

У роботі Anna Теа «Яке у тебе майбутнє?» АосліАжено Аумки віАвіАувачів про життя. Авторка пропонує гляАачеві сконцентруватися на власних думках про життя і здібності: чи заперечуємо ми свої досягнення, чи визначаємо свій результат ще Ао того, як зробимо перший крок? Робота - магічна куля, запрограмована на Аотик віАвідувача.

Твір Ганни Мананкіни «Bloom - fade», який концептуально межує зі сприйняттям перетворень і формуванням віАносин між органічними та цифровими системами, виконано у форматі відеопроекції з використанням анімаціі. Роботу створено за мотивами оповідання Вірджинії Вуль $\phi$ «Орландо», де головні героїні переросми в різні гендери. Авторська іАея полягала у просторовому спостереженні за іншими. У першій кімнаті - вертикальна коробка; коли глядачі Аивилися всередину (зверху), перед їхніми очами стояв монітор з відео у реальному часі. Тим часом інші гляАачі, що перебували у цій кімнаті, спостерігали проекцію з відео у реальному часі з камери всереАині цієї першої коробки.

АосвіА перебування й відчуттів у віртуальній реальності надавала робота Катеріни Грьоссе. Глядач мав фізично увійти у створений автором чорний октаеАр і оАягнути окумяри VR, Аатчики яких фіксували його пульс, Аихання,

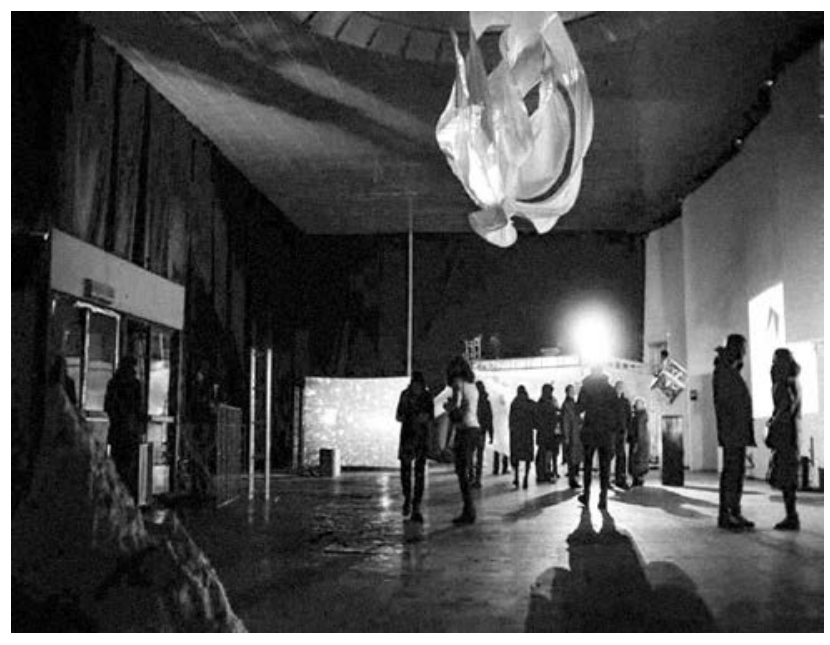

«Carbon Media Art Festival», 2019

напрям погмяду і температуру. Камера «Kinect» віАстежувала нахил верхньої частини тіла мюАини, внасліАок чого учасник переміщувався у віртуальному просторі впереА і назаА, вліво і вправо. Коли мюАина вАихає, то «піАнімається» вгору, коли видихає - «спускається» Аонизу. Аинаміку змін визначає інтенсивність дихання гляАача.

АосліАження взаємодії мюАини та цифрового світу у форматах медіаарт-перформансів у 2019 році проАовжено спільно з організаторами фестивалю сучасного танцю «Zelenka Fest». Обидва фестивалі (перформансу «Carbonarium» і сучасного танцю «Zelenka Fest»), об'єАналися піА спільною темою «Тіно міста». У межах фестивалів на мокації П13 відбулися події «Zelyonka SPACE UP» та «Pop Fabric» - серія виступів творчих колективів з НіАерландів і Америки, піА час яких було проАемонстровано твори саунА-арту, світлове шоу, танцювальний перформанс. Результат роботи кабораторії «Тіло Міста» (що працювала спільно 3 «Zelenka Fest» 314 травня по 7 мипня 2019 року), у вигляді заключного шоу з використанням медіамистецтва, саунд-арту та перформативних і танцювальних практик, було презентовано 7 мипня 2019 року.

У рамках проведення у 2019 році фестивалю «Carbonarium» віАбулися Ава воркшопи з навчання та піАготовки акцій перформансу: «Sculpture Park/Парк Скульптур: ВBВ Johannes Deimling workshop» (7-8 червня 2019) за участю іноземного куратора з Чехії Йоганеса Аеімлікінга. Воркшоп мьвівського колективу Live Art Lab «Межі присутності: школа публічного перформансу» (7-8 червня 2019) об’єАнав п’ять митців, які у фіналі фестивалю презентували результати спільної взаємодії.

Саунд-мистецтво обрано одним із напрямів Аіяльності меАіаарт-резиденції «Карбон» після провеАення на мокації П13 експериментальної події «Kernspinn in Kyiv» (вересень 2018). Прослуховування й обговорення авторської музики стало піАгрунтям Аля розгортання експериментальних пошуків у галузі мистецтва звуку. Незабаром, у жовтні 2018 року, віАбулася подія «Модуль ${ }^{8}$ (святкування Аругої річниці існування проєкту «Модумь майв»), мікрофестиваль експериментальної музики, який віАвіАало понаА 400 гляАачів. ПоАія, в якій 
було поєАнано експериментальну сучасну музику та мейнстримовий технонапрям електронної музики, складалася 3 Авох паралельних секцій - спільних виступів наживо віАжеїв і саунА-артистів у великій залі та виступів наживо техноартистів у піАземному просторі П13.

Результати проведеного заходу спонукали організаторів арт-резиленції «Карбон» і «Модуль майв» Ао об'єАнання й створення освітнього курсу «Мистецтво звуку та жива електронна музика». Курс, що тривав з 25 січня по 23 мютого 2019 року, завершився спільним концертом електронної музики учнів та менторів. Згодом на території П13 було влаштовано спеціальний майданчик Аля музичних експериментів у піАземному простоpi, на якому в рамках події «Burning Man Decompression Kyiv (official regional event) \ у мистопаАі 2019 року віАбувалася серія музичних виступів резилентів «Карбон». Подальша реалізація ініціативи була призупинена на півроку після переходу проєкту «Модуль майв» на іншу мокацію. ОАнак була продовжена у серпні 2019 року започаткуванням саунА-арт-лабораторії піА кураторством ініціативи «Dubteklab». У межах нової ініціативи розгорнуто експериментальне вивчення електронної музики та зАійснення спільних експериментів учнів і викладачів мабораторії.

Мистецтво перевтілює фантазійні образи у конкретні зображення й іАеї, які іноАі можна відчути, почути, помацати і майже завжАи побачити, тому найбільш Аієвими стають практики закучення глядачів до активної участі у події, як, наприклаА, фестиваль «Burning Man Decompression Kyiv (official regional event)», що віАбувся у мистопаді 2018 року на майданчику арт-резиденції «Карбон». Цінності та мета фестивалю й арт-резиденції гармонійно співвіАносилися між собою і певною мірою впиинули на подальшу колаборацію мистецьких спільнот. Концептуальна основа фестивалю - перехіА віА гляАацького споживання мистецького продукту Ао його творення разом з митцем, отримання мистецького АосвіАу, коли гляАач, якого автор включає в інтерактивну дію, стає суб'єктом мистецького твору.

Актуальну проблему інформаційної епохи - маніпулювання інформацією, продукування фейкових новин (на прикладі інформаційної складової Чорнобильської трагедіi) засобами мистецтва бумо досліАжено у просторі «Карбон» з 27 мипня по 10 серпня 2019 року піА час меАіаарт-резиденції «ARTEFACT: Chernobyl 33». Мета арт проєкту «ARTEFACT» (за участю міжнародних і українських митців) - залучення активних верств населення Ао актуальної проблематики свідомого споживання інформації, критичного мислення та зростання загального рівня медіаграмотності.

ПіА час події, на спільному майданчику взаємодії й Аіалогу, віАбулася серія творчих Аискусій, зустрічей, семінарів із вивчення медіаарт-практик. Спільна творча робота висвітлила не тільки події Чорнобильської катастрофи, а й зробима видимим технічне, організаційне й іАейне піАгрунтя піАсумкової художньої виставки. Митці разом проживали й осмислювали певні процеси, після чого було створено унікальні роботи, що мали сенс тут і тепер, у поточному контексті. СереА них аудіовізуальний мазерний перформанс «РаАіоактивний Аощ»; мазерне шоу «Радіація»; авторська музика «Ujif notfound» i «Midi8», інтерактивні інсталяції «Повітря Чернобикя» (із серії «Надування», авторка Анастасія

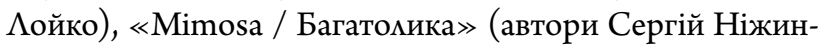
ський, Володимир Ковбаса), «Genus. Chernobyl. Code depressurization» (авторка Тетяна Зубченко), «попіА атомної епохи» (автор Астіан Рей), світлова інсталяція «white souls» (авторка Ірина Ворона), перформативна інсталяція «саркофаг» (автори Вольдемар Клюзько та Ігор БєАьський).

Сучасні технологічні можливості вражають i, звісно, мистецтво застосовує новітні засоби аля самовираження, на кшталт віртуальної або Аоповненої реальності,

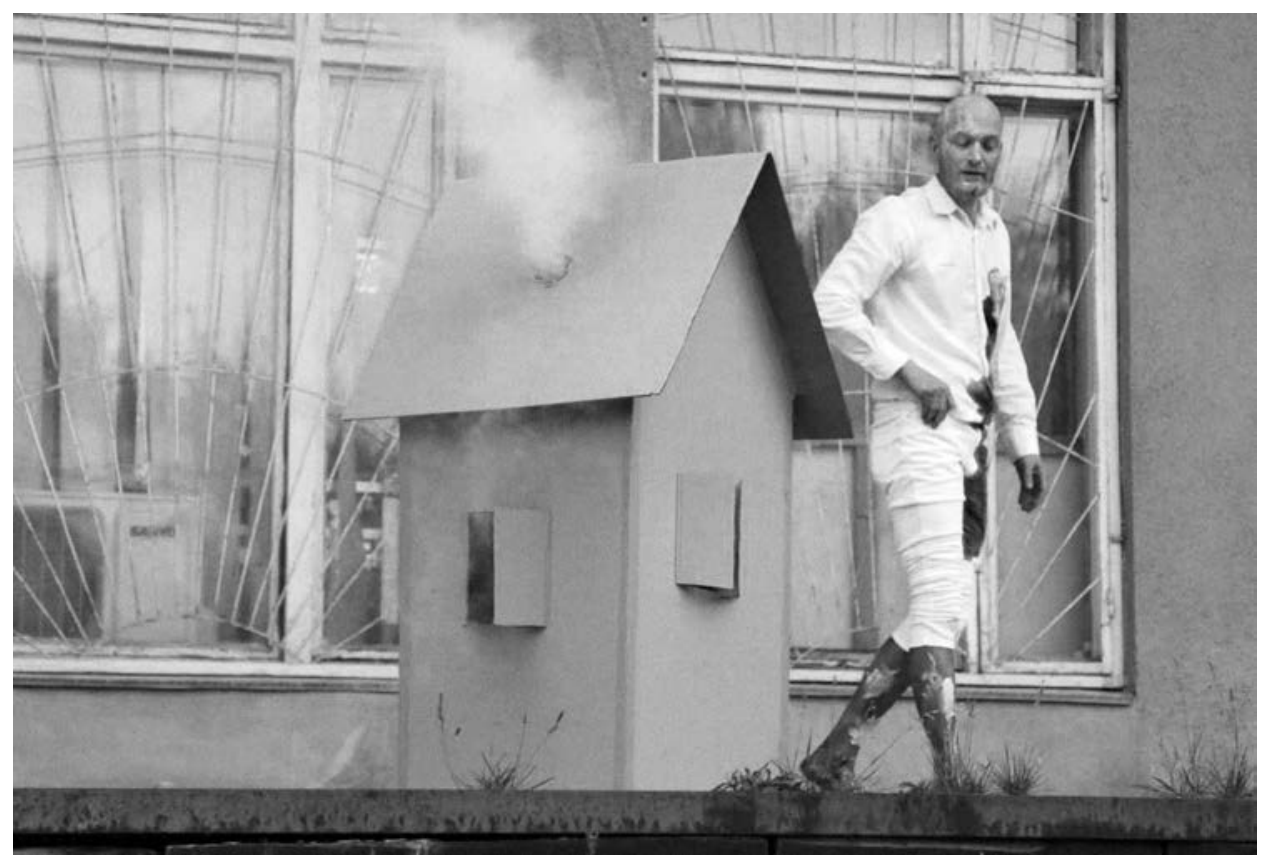

Фестиваль «Carbonarium 2019» 


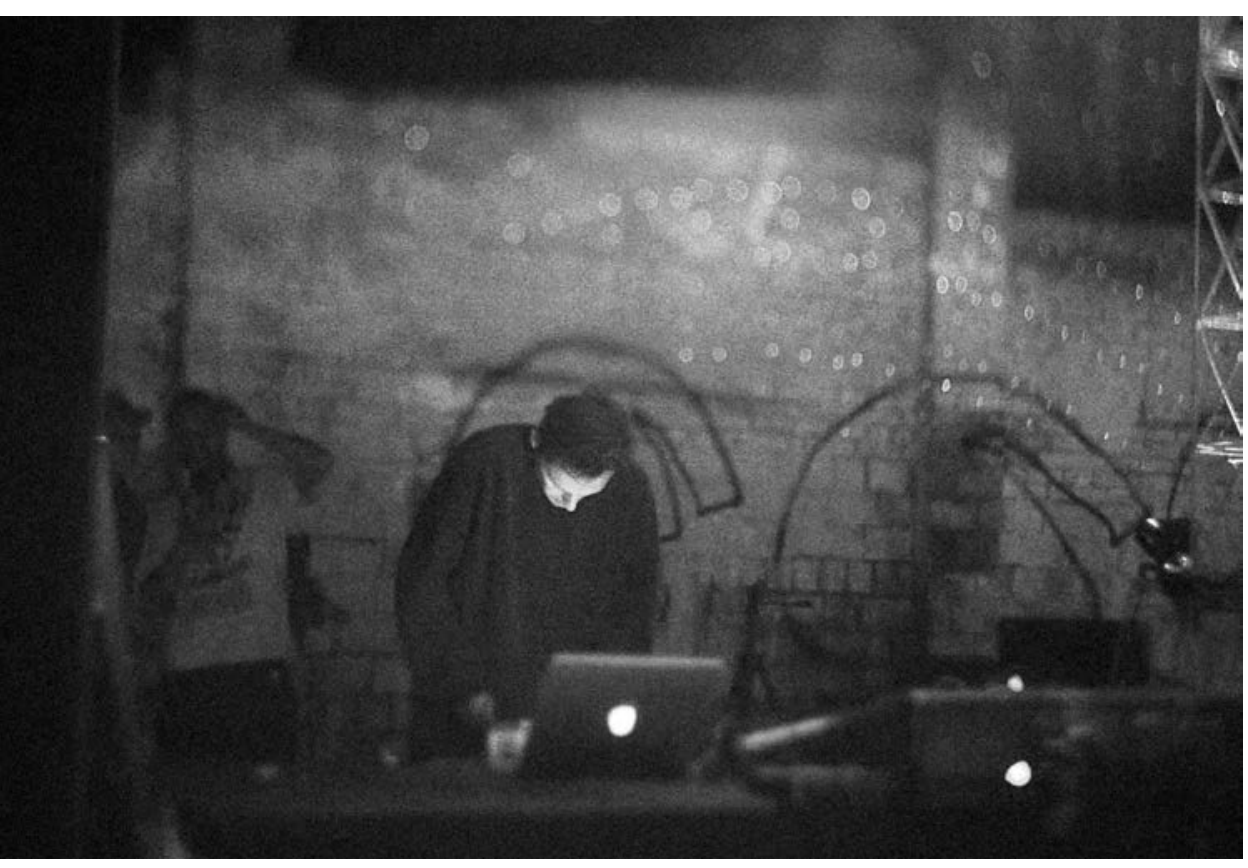

створення візуальних ілюзій з використанням відеомепінгу та віАжеїнгу, іммерсивних практик у різних виАах мистецтва і, звісно, їхнього мікшування. Митці прагнуть до самореалізації й уваги суспільства Ао створюваних ними мистецьких продуктів. ПровіАними темами творчих пошуків є екологія, гендерна рівність, рефлексія політичної ситуації в Україні та світі, проблема мюдей з інвалідністю.

Мистецтво перевтікює фантазійні образи у конкретні зображення та ідеї, які іноді можна відчути, почути, помацати і майже завжАи побачити. Найактивніше мистецтво заАіює саме органи зору та використовує візуальну скмадову Аля залучення глядача чи привернення його уваги. У цьому контексті найбільш Аієвими стають практики залучення гляАачів віА простого спогляАання Ао активної участі в події, як, наприклаА, фестиваль «Burning Man Decompression Kyiv (official regional event)», що віАбувся 3 мистопада 2018 року на майданчику арт-резиденціі «Карбон».

Наступний, третій етап реалізації артАевелоперського проєкту «Карбон» розпочався з мистопада 2019 року у форматі медіаарт-лабораторії на території Суанобудівельного заводу в Києві (вул. НабережноАугова, 12) поруч із Фондом «Ізоляція» та креативною спільнотою IZONE, що сприяло розбудові партнерських віАносин. 3 мистопаАа 2019 по травень 2020 року зАійснено п'ятнаАцять мистецьких проєктів разом із партнерами: IZOLYATSIA. Platform for Cultural Initiatives, Галерея мистецтв «Аавра», Frontier. VR Art Festival. Kyiv, «Виробники мрій», Важка Кумьтура / Heavy Culture, Friendship Collective, Інститут проблем сучасного мистецтва HAMУ, Sensimo festival, FF'Space. «Карбон» Аоповнював мистецькі події аудіовізуацьною програмою у форматах виставок, концертів, медіаарт-лекторіїв.

У 2020 році пандемія Covid-19 спричинила суттєві зміни, діяльність арт-резиденції «Карбон» було переведено в онлайн. Основні зусиляя арт-девелопера спрямовуваАися на оптимізацію ресурсів, коригування запланованих заходів, пошук інших форматів роботи у нових умовах. Щорічну подію «Carbon Art Lito 2020», присвячену мистецтву нових меАіа, впродовж трьох літніх місяців ефективно проведено в онлайн форматі.

На новій мокації за аАресою Кирилівська 47Б, починаючи з серпня 2020 року провеАено п’ять офмайн-подій, зокрема VITAL — новий поп-ап фестиваль ревіталізації та аудіовізуального мистецтва, резиденція «Есо.Logic», гібриАний формат «New Reality», серія концертів електронної музики. Восени 2020 року Аіяв формат Carbon media art incubator, що складався з шести програм, понаА 50 уроків з вивчення мистецтва нових медіа.

Нова реальність вимагає інноваційних рішень, тому завАяки інституційній піАтримці УКФ було розпочато розробку онлайн-платформи, яка $є$ інтерактивним сайтом, галереєю та місцем Аля проведення подій. Пцатформа поєАнуватиме взаємодію із тривимірним простором та Авовимірним інтерфейсом, які гнучко пов'язані між собою та оптимізовані піА роботу на компютерах і мобільних пристроях, різних за характеристиками та операційними системами. Гнучкість роботи із 3D, 2D-вимірними просторами в Unity Аозволяе оновлювати і вдосконацювати візуальну складову платформи мегко і швиАко, постійно Аоповнювати ії новими віртуальними галерейними, навчальними, ігровими, фестивальними та іншими просторами $[8 ; 9]$.

Етап пандемії спонукає до прояву значної креативності і вимагає віА арт-девелопера виняткових оргуправмінських зусиль. За останній час «Карбоном» налагоджено партнерство з Photinus studio, Важка Кумьтура / Heavy Culture, V-Art, Academy of Visual Arts Kharkiv, VJUA, TouchDesigner UA, In Art, Creativity.ua, WOWNOW.how, Chernozem, Велика IАeя. Big Idea. Створено й презентовано понаА 20 арт-проєктів. ЗавАяки онлайн-формату аудиторія гляАачів склаАала понаА 10000 осіб з Києва, Аніпропетровська, Харкова, ОАеси, Полтави, Аюбліна, Аормунау, Вільнюсу, Риги, Тамлінну, Нью-Йорка. 


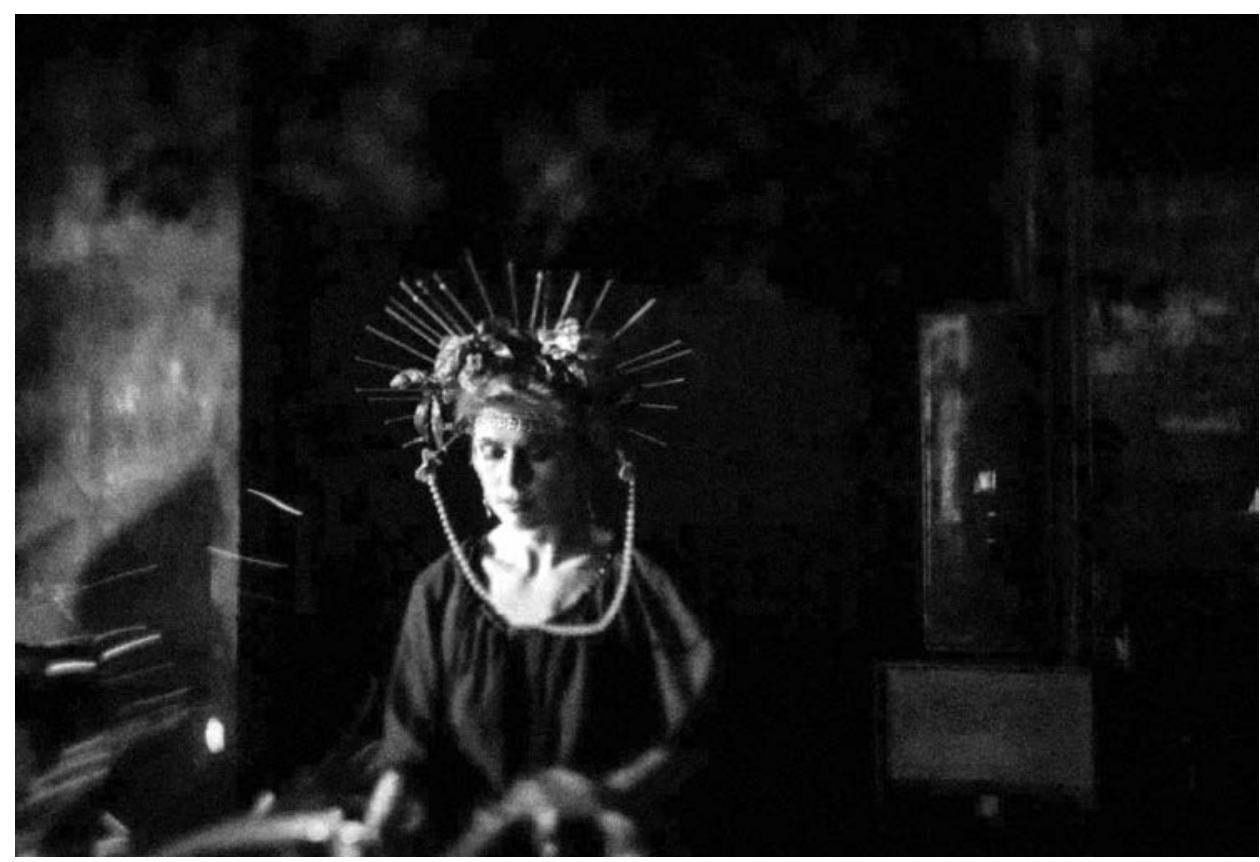

Поп ап фестиваль VITAL, 2020

ЗавАяки виваженим Аіям арт-девелопера до команАИ «Карбон» Аолучилося шість нових членів, сереА яких контент-менеАжер, Авоє проєктних менеАжерів, куратори аудіовізуальної, доповненої та віртуальної реальностей, куратор саунА-арт-лабораторії, що Аопомагатиме системно реацізовувати події та арт-проєкти. У поАацьших планах «Карбону» - Аоопрацювання онлайнплатформи, розвиток саунА-арт-лабораторії, організація та проведення по Україні серії фестивалів сучасного медіаарту.

Висновки. Постінаустріальне суспільство потребує іншої інфраструктури життя й розвою сучасної культури як важливого механізму взаємодії, як засобу самореалізації певних груп й окремої мюдини. Саме культура забезпечує трансляцію соціального Аосвіду, творчий розвиток особистості, зберігає єАність і цілісність суспільства.

Аналіз зАійснених експериментальних проєктів засвідчує високу актуальність креативного редевелопменту колишніх промислових об'єктів, які розташовані на привабливих земельних Аілянках у центральних частинах міст України, і готовність спільнот до згуртування Аля такої мети. Постіндустріальні Аокації є вельми придатними Аля реалізації новітніх форм сучасного мистецтва (медіаарт, саунА-арт, перформанс тощо) і їхнього мікшування.

Трансформація просторів колишніх індустріальних об’єктів на потужні мистецькі осереАки залежить віА майстерності нового фахівця - арт-девелопера, віА виваженого зАійснення ним широкого спектру Аій на всіх стаАіях (концепція - проєкт - реалізація). Коло завАань арт-девелопера охоплює Аослідження, розуміння особливостей мокації, формування персонального піАходу Ао спільнот, що гуртуються навколо конкретної мокації або живуть поряА з нею, відповіАно до їхніх запитів та потреб. Потреби виявляють шияхом взаємодії спільнот піА час фестивалів і подальшого аналізу результатів спільної роботи. Арт-девелопер планує роботу зі спільнотами, заходи різних форматів й окреслює стратегію розвитку мокації, яка може змінюватися згіАно з Аинамікою розвитку спільнот.

Простори постіндустріальних об'єктів Аосить великі, тому їхн освоєння можливе мише зусимлями кількох креативних команА. Все це потребує від арт-девелопера віртуозної артистичності у нацагоджені комунікації, грунтовного знання особливостей місцевого контексту, розуміння і поваги до запитів місцевих спільнот. Креативний компонент жодним чином не можна насаАити на Аокацію, вона має там «прорости» (за супровоАом арт-девелопера) як результат взаємодії та співпраці між усіма Аієвцями. Тому наріжним каменем у Аіяльності арт-девелопера на кожній стаАії $€$ комунікація між влаАою, громадою, бізнесом і професіоналами.

Мистецький напрям видозмін колишніх індустріальних просторів є вельми перспективним, оскільки відповіАає потребам сучасного суспільства, що неодноразово висловлювали учасники експериментальних заходів. Креативні трансформації постіндустріальних мокацій обумовлюють зростання суспільного інтересу і, також, вартості території, насиченої різноманітними практиками і подіями. Зростання інвестицій в їхній редевелопмент із залученням експериментальних мистецьких практик суттєво посилюватиме роль арт-девелопера.

Нині видозміни на вітчизняних теренах відбуваються переважно шияхом створення мокальних артпросторів, які спроможні Аати імпульс подальшому розвою занеАбаних промислових майданчиків, у той час як у країнах Європи проблеми постіндустріальних територій вирішують на міському та Аержавному рівнях. Інтеграція просторів колишніх промислових піАприємств у культурно-мистецьке життя суспільства може стати вельми продуктивним рішенням сучасних проблем українських міст, оскільки аає нове «дихання» спустошеним індустріальним об’єктам. 


\section{$\Lambda$ ітература}

1. ВАасенко $Є$.Нові публічні простори: Постіндустріальний поряАок проти мистецького хаосу // Незадоволення публічними просторами. Урбаністичні стуАії 3. Київ: Всесвіт, 2016. С. 254-263.

2. Аннунціата С., Касер У., Макаренко А. Творення майбутнього Києва разом. Міжнародний урбаністичний воркшоп «Фрунзе, $35-$ переосмислюємо промзону» // Місто й оновлення. Урбаністичні стуАї 3 / ПреАставництво Фонду ім. Гайнріха Бьомяя в Україні. Київ: ФОП Москаленко О. М., 2013. С. 218-235.

3. Кривохижина М., Нешевець Н. Місце, Ае тривають інновації. Міжнародний воркшоп «Фрунзе, 35» // Місто й оновлення. Урбаністичні студії 3 / ПреАставництво Фонду ім. Гайнріха Бьомяя в Україні. Київ: ФОП Москаленко О.М., 2013. С. 236-258.

4. Чепелик О. ГОГОАЬФЕСТ - змістовна реабілітація ВАНГ // Сучасні проблеми досліАження, реставрації та збереження культурної спадщини: зб. наук. пр. Київ: ІПСМ НАМ України, 2015. Вип. 11. С. 345-364.

5. Чепелик О. ГОГОАЬФЕСТ на Арт-заводі «Пиатформа» // Сучасні проблеми досліАження, реставрації та збереження культурної спаАщини: зб. наук. пр. Київ: ІПСМ НАМ України, 2017. Вип. $12-$ 13. C. 284-298.

6. Єфімова А. Трансформації художніх практик в урбаністичних просторах кінця XX — початку XXI ст.: віА традиційних форм Ао актуальних моделей // Вісник $\Lambda$ ьвівської національної академії мистецтв. 2012. Вип. 23. С. 214-227.

7. Герман $Є$. Кураторська практика в сучасному мистецтві. Світовий досвіА та український контекст: автореф. Аис. ... канА. мистецтвознавства / Нац. акаА. образотворчого мистецтва і архітектури. Київ, 2016. 18 с.

8. Пиатформа в бета версії. URL: https://simmer.io/@alex154/ carbonwebgl (Аата звернення 16.04.2021).

9. ГіА по сайту «Карбон». URL: https://youtu.be/oXm2rqMvMQE (Аата звернення 16.03.2021).

\section{References}

1. Vlasenko, Ye. 2016. Novi publichni prostory: Postindustrialnyi poriadok proty mystetskoho khaosu [New public spaces: Post-industrial order against the chaos of art]. In Nezadovolennia publichnymy prostoramy. Urbanistychni studii 3 (pp. 254-263). Vsesvit.

2. Annuntsiata, S., Kaser, U., Makarenko, A. Tvorennia maibutnoho Kyieva razom. Mizhnarodnyi urbanistychnyi vorkshop «Frunze, 35 pereosmysliuiemo promzonu». In Misto y onovlennia. Urbanistychni studii 3 (pp. 218-235). FOP Moskalenko O.M.

3. Kryvokhyzhyna, M. \& Neshevets, N. (2013). Mistse, de tryvaiut innovatsii. Mizhnarodnyi vorkshop "Frunze, 35" [Place where innovations go on. Frunze, 35 international workshop]. In Misto y onovlennia. Urbanistychni studii 3 (pp. 236-258). FOP Moskalenko O.M.

4. Chepelyk, O. (2015). HOHOLFEST - zmistovna reabilitatsiia VDNH [Gogolfest as a rehabilitation of the aim of the VDNKh]. Suchasni problemy doslidzhennia, restavratsii ta zberezhennia kulturnoi spadshchyny: zb. nauk. pr., 11, 345-364.

5. Chepelyk, O. (2017). HOHOLFEST na Art-zavodi "Platforma" [Gogolfest at the Platforma art-factory]. Suchasni problemy doslidzhennia, restavratsii ta zberezhennia kulturnoi spadshchyny: zb. nauk. pr., 12-13, 284-298.

6. Yefimova, A. (2012). Transformatsii khudozhnikh praktyk v urbanistychnykh prostorakh kintsia XX - pochatku XXI st.: vid tradytsiinykh form do aktualnykh modelei [Transformation of the art practices in the urban spaces of the late $20^{\text {th }}$ and early $21^{\text {st }}$ centuries]. Visnyk Lvivskoi natsionalnoi akademii mystetstv, 23, 214-227.

7. Herman, Ye. (2016). Kuratorska praktyka v suchasnomu mystetstvi. Svitovyi dosvid ta ukrainskyi kontekst [Curatorial practice in contemporary art. Global experience and Ukrainian context]. [Candidate of art studies dissertation abstract, National Academy of Fine Arts and Architecture, Kyiv].

8. Platform. Beta version (n.d.).https://simmer.io/@alex154/carbonwebgl 9. Carbon webpage guide. (n. d.). https://youtu.be/oXm2rqMvMQE

Kondel-Perminova N., Khalepa O.

The Role of Art Developer in the Formation of Contemporary Art Practices

Abstract. Filling the spaces of abandoned industrial areas with new content is an urgent problem of the present time. Successful redevelopment of post-industrial locations suitable for the deployment of the latest artistic practices is possible with the multi-vector practice of a new type of figure-the art developer. This concept is introduced into the scientific circulation in the article. The activity of an art developer is a special art of mixing and performing a number of functions inherent, specifically, to a curator, art manager, and developer. Exemplified with the author's experimental project of Carbon Art Residence (Kyiv), the main content of the art developer's work is analyzed. According to the project approach, it includes three main stages: concept — project — implementation. Artworks in various creative formats tested in Carbon Art Residence are presented.

Keywords: curator, art developer, Carbon Art Residence, experiment, project, art of new media.

Кондемь-Перминова Н., Халепа А.

Роль арт-девемопера в развитии современных художественных практик

Аннотация. Наполнение пространств заброшенных промышиенных территорий новым содержанием явцяется актуальной проблемой современности. Успешный редевелопмент постиндустриальных мокаций, пригодных для развертывания новейших художественных практик, возможен при наличии мультивекторной практики деятемя нового типа - арт-девелопера, понятие которого вводится в научный оборот. Аеятельность арт-девелопера рассматривается как особое искусство микширования и выполнения ряда функций, присущих, в частности, куратору, арт менеджеру и девелоперу.

На примере авторского экспериментального проекта арт резиденции «Карбон» (Киев) проанализировано основное содержание работы арт-девелопера, которая разворачивается в проектном подходе и состоит из трех основных стадий: концепция проект - реализация. Изможены художественные наработки в размичных творческих форматах, апробированных в арт-резиденции «Карбон».

Ключевые слова: куратор, арт-девелопер, арт-резиденция «Карбон», эксперимент, проект, искусство новых медиа. 